Saskatchewan. Blue Jay 47:216.

7. - 1990. Olivaceous Cormorant - first record for Canada. Blue Jay 48:154-155.

8. CHYTYK, P. 1990. Saskatchewan's first Black-legged Kittiwake. Blue Jay 48:112-114.

9. DECHKA, S.S. 1990. Saskatchewan's first Garganey observations. Blue Jay $48: 320$.

10. HOLMES. P.M. 1990. Scissor-tailed Flycatcher at Eastend, Saskatchewan. Blue Jay 48:221.

11.HOOPER, D.F. 1990. House Finch and American Woodcock at Somme,
Saskatchewan. Blue Jay 48: 47-48.

12. KREBA, R. 1990. Field checklist of Saskatchewan birds. Sask. Mus. Nat. Hist.

13. LAWRENCE, F. 1990. Prothonotary Warbler in Regina. Blue Jay 48:45-46.

14. STEPNEY, P. H. R. 1981. Checklist of Albertan birds. Provincial Museum of Alberta.

15. WEDGWOOD, J. 1990. Ross' Gull near Saskatoon, Saskatchewan. Blue Jay 48:158-161.

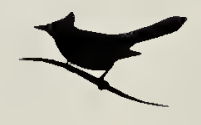

\title{
Christmas Bird Count Update - Val Marie, Saskatchewan
}

The following count was received too late for inclusion in the compiled results. The count was carried out on 16 December 1990 . Temperature $-20^{\circ}$ to $-10^{\circ} \mathrm{C}$, wind light, snow cover was $5-10 \mathrm{~cm}$, overcast with light snow in morning, sunny in afternoon. In total, 13.5 hours were spent covering $148 \mathrm{~km}$ by vehicle and $12 \mathrm{~km}$ on foot.

Bald Eagle, 1; Northern Goshawk, 1; Rough-legged Hawk, 1; Golden Eagle, 3; Gray Partridge, 12; Ring-necked Pheasant, 82; Sharp-tailed Grouse, 5; Rock Dove, 1; Great Horned Owl, 4; Short-eared Owl, 2; Horned Lark, 125; Black-billed Magpie, 82; Northern Shrike, 2; Snow Bunting, 1,117; Evening Grosbeak, 1; House Sparrow, 186. 16 species, 1,625 individuals.

Observers: Lynn Grant, Allan Hall, Don McDonald, Cheryl Penny, Lise Perrault, Jacques Saquet. 